\title{
Effects of eltoprazine hydrochloride (DU 28853) on maternal behavior in mice
}

\author{
LESLIE R. MEEK and ERNEST D. KEMBLE \\ University of Minnesota-Morris, Morris, Minnesota
}

\begin{abstract}
The maternal behavior of CD-1 mice was observed following treatment with three dosages of the antiaggressive drug eltoprazine hydrochloride $(1.0,2.0$, and $4.0 \mathrm{mg} / \mathrm{kg})$ or saline. The drug had no reliable effect on latencies to retrieve the first pup, all pups, or to initiate nursing. Nursing duration was also unaffected by drug treatment. The results suggest that eltoprazine alters a narrower range of behaviors than do related compounds, and that it may specifically inhibit agonistic behaviors.
\end{abstract}

Eltoprazine hydrochloride (DU 28853) is a recentaddition to a family of phenylpiperazine compounds (DU 27716, 27725, 28412), all of which strongly inhibit conspecific attack behavior while leaving defensiveness unaltered or increased (e.g., Bradford, Olivier, van Dalen, \& Schipper, 1984; Flannelly, Muraoka, Blanchard, \& Blanchard, 1985; Olivier, 1981; Olivier, Mos, \& Brain, 1987). Although such selective antiaggressive effects are encouraging, studies of other species-typical behaviors are needed to evaluate these compounds more fully. Previous investigations of DU 27716, for example, revealed that the drug inhibited male copulatory behavior (Flannelly, Lim, Diamond, Blanchard, \& Blanchard, 1985), predation (Schultz \& Kemble, 1986), play (Selseth \& Kemble, 1988), exploration (Kemble, Thornton, \& Schultz, 1987), and maternal behavior (Kemble \& Schultz, 1989), as well as conspecific aggression. Since initial studies revealed that eltoprazine also inhibits play and predatory behaviors (Meek \& Kemble, in press; Olivier et al., 1987), this drug might have a broader range of behavioral effects as well. It therefore seemed of interest to explore the effects of eltoprazine on other speciestypical behaviors. Although Olivier et al. (1987) report briefly that pup care is increased by eltoprazine treatment, their observations were carried out during tests of maternal aggression. Thus, it is unclear to what extent drug effects on maternal behavior were obscured by agonistic interactions of the females with intruding males. This experiment therefore investigated the effects of drug treatment on maternal behavior in the absence of intruding males.

\section{METHOD}

The subjects were 48 nulliparous CD-1 albino mice that weighed $29.2-47.8 \mathrm{~g}$ at the time of testing. The mice were individually housed

The authors would like to thank Berend Olivier for kindly supplying the eltoprazine used in this experiment. Please address correspondence to Ernest Kemble, Division of Social Sciences, University of Minnesota-Morris, Morris, MN 56267. and tested in $19.0 \times 26.0$ stainless steel cages with a 4.0-4.5 substrate of sawdust. The mice were maintained on a 12-h light/dark cycle, and had ad-lib access to Purina Lab Chow and water throughout the experiment. Litters were reduced to 6 pups for testing, with the remaining pups returned at the conclusion of observations.

The females were housed with males until noticeably pregnant, individually housed for at least $72 \mathrm{~h}$ prior to partuition, and tested 24-36 h postpartum. The females were assigned randomly to groups $(n=12)$ designated to receive low $(1.0 \mathrm{mg} / \mathrm{kg})$, medium $(2.0 \mathrm{mg} / \mathrm{kg})$, or high $(4.0 \mathrm{mg} / \mathrm{kg})$ doses of eltoprazine or an equivalent volume of saline. All pups were removed from the home cage and the female then received the appropriate drug by intraperitoneal injection. Thirty minutes later, the 6 pups were scattered about the cage floor and a 30 -min observation period was begun. Latencies to retrieve the first pup, all pups, to initiate nursing, and duration of nursing were recorded with stopwatches. No females injured their pups during this experiment.

\section{RESULTS AND DISCUSSION}

Mean latencies to retrieve the first pup (saline, $M=$ $3.3 \mathrm{~min}$; low, $M=2.8 \mathrm{~min}$; medium, $M=0.3 \mathrm{~min}$; high, $M=0.6 \mathrm{~min}$ ) and to retrieve all pups (saline, $M$ $=10.9 \mathrm{~min}$; low, $M=8.8 \mathrm{~min}$; medium, $M=4.7 \mathrm{~min}$; high, $M=6.6 \mathrm{~min}$ ) decreased at the higher drug doses. The decrease, however, was due primarily to the failure of 2 mice (saline $=1$, low $=1$ ) to retrieve any of their pups. Analyses of variance provided no suggestion of a drug effect $(F \mathrm{~s}<1.0)$. Similarly, although mean latency to nurse decreased at the highest dose (saline, $20.8 \mathrm{~min}$; low, $M=23.5 \mathrm{~min}$; medium, $M=21.6 \mathrm{~min}$; high, $M=$ $14.3 \mathrm{~min})$, there were no statistically significant group differences $(F<1.0)$. Nursing durations overlapped extensively among the groups $(M \mathrm{~s}=5.7-15.3 \mathrm{~min})$, and there were no significant group differences $(F<1.0)$.

These findings are generally consistent with those of Olivier et al. (1987) in indicating that eltoprazine treatment has no effect on, or may somewhat enhance, maternal behavior, but contrasts sharply with the major disruptions of pup care noted after treatment with DU 27716 (Kemble \& Schultz, 1989). The fact that eltoprazine treatment inhibits predation, play (Meek \& Kemble, in press; Olivier et al., 1987), and conspecific attack while having no effect on maternal behavior suggests that the effects of this drug may be restricted to behaviors that have 
at least some agonistic components. Investigation of a broader range of species-typical behaviors would be useful in addressing this issue.

\section{REFERENCES}

Bradford, L. D., Olivier, B., van Dalen, D., \& Schipper, J. (1984). Serenics: The pharmacology of fluprazine and DU 28412. In K. Miczek, A. Kruk, \& B. Olivier (Eds.), Ethnopharmacological aggression research (pp. 191-207). New York: Liss.

Flannelly, K. J., Lim, H. L., Diamond, M., Blanchard, D. C., \& BLANCHARD, R. J. (1985). Fluprazine hydrochloride decreases copulation in male rats. Pharmacology, Biochemistry \& Behavior, $22,1-4$.

Flannelly, K. J., Muraoka, M. Y., Blanchard, D. C., \& BlanCHARD, R. J. (1985). Specific anti-aggressive effects of fluprazine hydrochloride. Psychopharmacology, 87, 86-89.

Kemble, E. D., \& SChultz, L. A. (1989). Effects of fluprazine hydrochloride on maternal behaviour in mice. Behavioural Processes, 18, 61-69.

Kemble, E. D., Thornton, A. E., \& Schultz, L. A. (1987). Some fear-potentiating effects of fluprazine hydrochloride in mice. Aggressive Behavior, 13, 269-280.

MeEK, L. R., \& KembLe, E. D. (in press). Effects of eltoprazine hydrochloride on predatory aggression in rats. Psychological Record.

Olivier, B. (1981). Selective anti-aggressive properties of DU 27725: Ethological analyses of intermale and territorial aggression in the male rat. Pharmacology, Biochemistry \& Behavior, 14, 61-77.

Olivier, B., Mos, J., \& Brain, P. F. (1987). Ethnopharmacology of agonistic behaviour in animals and humans. In B. Olivier, J. Mos, M. Tulp, B. Berkelmans, \& P. Bevans (Eds.), Serotonergic modulation of agonistic behaviour (pp. 162-186). Dordrecht: Martinus Nijhoff.

Schultz, L. A., \& Kemble, E. D. (1986). Prey-dependent effects of fluprazine hydrochloride on predatory aggression in northern grasshopper mice (Onychomys leucogaster) and rats (Rattus norvegicus). Aggressive Behavior, 12, 267-275.

Selseth, K. J., \& Kemble, E. D. (1988). Fluprazine hydrochloride decreases play behavior but not social grooming in juvenile rats. Bulletin of the Psychonomic Society, 26, 563-564.

(Manuscript received April 13, 1990.)

\title{
Announcement
}

\author{
6th European Conference on Eye Movements \\ Leuven, Belgium \\ September 15-18, 1991
}

Call for Papers

Deadline: January 31, 1991

The 6th European Conference on Eye Movements will be held at the University of Leuven, September 15-18, 1991. Its aim is to promote the wider exchange of information concerning eye-movement research in all its diverse fields, and to encourage contact beween basic and applied research. The Conference will be of interest to psychologists, educational scientists, neurophysiologists, medical doctors, bioengineers, ergonomists, and others interested in visual science.

Papers and posters on the following topics are welcome: neurophysiology of eye movement, oculomotor system, measurement techiques, eye movements in perceptual and cognitive tasks, eye movements and reading, oculomotor disorders, and applied research. Papers integrating sensory sciences and higher order studies will be favored. Papers and posters should be in English, and paper presentations should not exceed 20 minutes.

One-page abstracts for spoken and poster presentations should be sent, by January 31, 1991, to: Laboratorium voor Experimentele Psychologie, Katholieke Universiteit Leuven, Tiensestraat 102, B-3000 Leuven, Belgium (e-mail: fpaas91@blekul11.earn (bitnet)).

Further information may be obtained from Géry d'Ydewalle or Johan Van Rensbergen at the address given above. 